\title{
Synthesis of Nepetoidin B
}

\author{
Vitaliy Timokhin ${ }^{\mathrm{a}}$ \\ Matthew Regner ${ }^{\text {a }}$ (D) \\ Yukiko Tsuji ${ }^{\mathrm{a}}$ \\ John Grabber ${ }^{b}$ \\ John Ralph*a \\ ${ }^{a}$ Department of Energy Great Lakes Bioenergy Research \\ Center and Department of Biochemistry, the Wisconsin \\ Energy Institute, University of Wisconsin, Madison, WI, \\ 53726, USA \\ jralph@wisc.edu \\ b U.S. Dairy Forage Research Center, USDA-ARS, 1925 \\ Linden Drive West, Madison, WI, 53706, USA
}

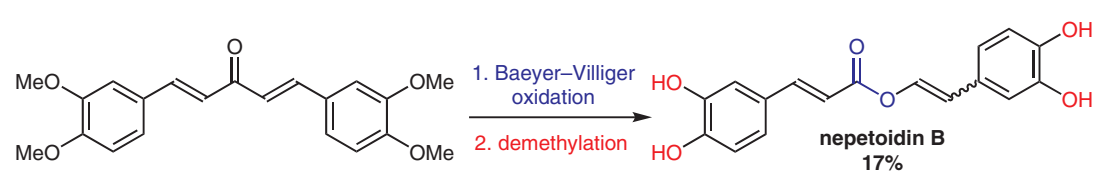

$17 \%$
Received: 16.02 .2018

Accepted after revision: 26.02.2018

Published online: 28.03 .2018

DOI: 10.1055/s-0036-1591556; Art ID: st-2018-b0110-I

License terms: cc)

Abstract The first synthesis of nepetoidin B in an overall yield of $17 \%$ was achieved in two steps through Baeyer-Villiger oxidation of commercially available 1,5-bis(3,4-dimethoxyphenyl)-1,4-pentadien-3-one with oxone to produce the tetramethylated nepetoidin $B$, followed by demethylation using boron tribromide.

Key words Baeyer-Villiger oxidation, demethylation, medicinal chemistry, natural products

Nepetoidin B (1) was initially isolated from Plectranthus caninus in 1975 as the $(Z, E)-\mathbf{1}$ isomer (Figure 1$).{ }^{1}$ Since then, $(Z, E)-\mathbf{1}$ and its corresponding stereoisomer, $(E, E)-\mathbf{1}$, have been isolated from a variety of plant species using solvent extraction and chromatographic purification. ${ }^{2-31}$ The amounts of $(Z, E)-\mathbf{1}$ and $(E, E)-\mathbf{1}$ vary from $9: 1$ to $1: 1$ in different plants, ${ }^{1,10}$ where the stereochemistry of the two isomers has historically been elucidated based on the analyses of $J$ coupling constants from NMR spectroscopic data. ${ }^{1-9,12,15-20}$

Nepetoidin's level in plants is rather low; in a recent isolation from $100 \mathrm{~kg}$ of Salvia miltiorrhiza Bunge (Danshen), extraction and purification yielded just $37 \mathrm{mg} .{ }^{27}$ Based on the genes, enzymes, and metabolites that have been associated with nepetoidin B, several mechanisms have been proposed for its biosynthesis: (1) condensation of the enol form of dopaldehyde with caffeic acid; ${ }^{1,5,15,19}$ (2) oxidative decarboxylation of rosmarinic acid, from which stereospecific loss of the pro- $R$ or pro- $S$ methylene proton during this process would result in the formation of $(Z, E)-\mathbf{1}$ or $(E, E)-\mathbf{1} ; 21,25$ and (3) decarboxylation of $p$-hydroxyphenylpyruvic acid and subsequent esterification with the enol form of 3,4-dihydroxyphenylacetaldehyde. ${ }^{25}$
Several studies have demonstrated potential biological applications for 1: it has shown antibacterial, antifungal, and free-radical scavenging properties, and it could be used as a chemotaxonomic marker. ${ }^{8-10,12,15,30-31}$ Furthermore, $\mathbf{1}$ is an inhibitor of xanthine oxidase and thus could help to regulate hyperuricemia in human gout, ${ }^{12}$ as well as inhibit the production of nitric oxide, which is stimulated by bacterial lipopolysaccharide. ${ }^{27}$ Surprisingly, in spite of its medicinal characteristics, there has been no reported synthesis of 1 to date. The commercial price of nepetoidin B varies from about $\$ 150 / \mathrm{mg}$ to about $\$ 5,000 / \mathrm{g}$, a price prohibitive to its use in research studies. In continuation of our work on the production of bioproducts from biomass, especially with regard to nepetoidin $\mathrm{B}$ and its potential incorporation into lignin in plant cell walls, we sought to design a synthetic route for its production. ${ }^{32}$

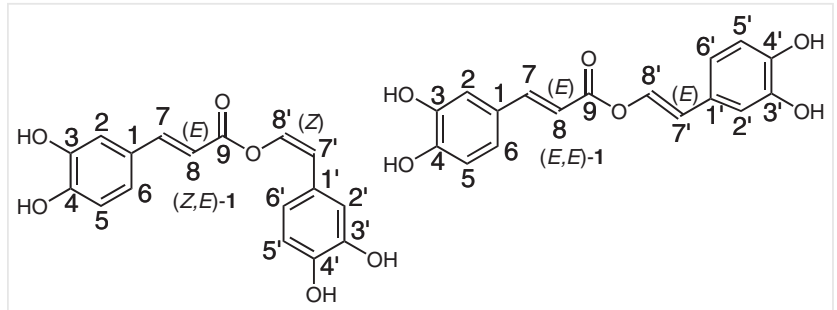

Figure 1 The two naturally occurring isomers of nepetoidin $B,(Z, E)-1$ and $(E, E)-\mathbf{1}$, isolated from plants

Herein, we report the first synthesis of nepetoidin B. Our synthetic route (Scheme 1) began with Baeyer-Villiger oxidation of commercially available 1,5-bis(3,4-dimethoxyphenyl)-1,4-pentadien-3-one (2) with oxone, based on a reported procedure for the transformation of $\alpha, \beta$-unsaturated ketones into their corresponding vinyl acetates. ${ }^{33}$ We optimized the reaction conditions for the stereospecific transformation of only one of the two symmetrical $\alpha, \beta$-unsatu- 

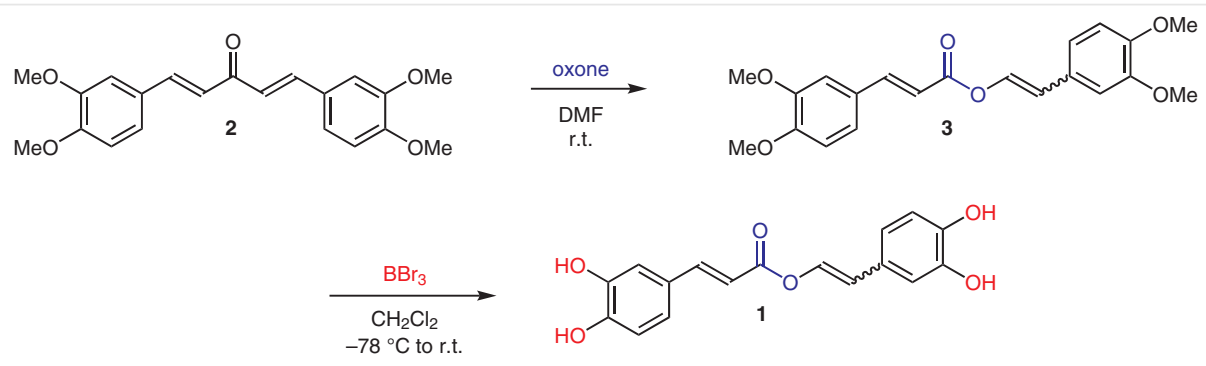

Scheme 1 Synthesis of nepetoidin B

rated ketones into its corresponding vinyl acetate; our final conditions afforded tetramethylated nepetoidin $\mathrm{B}[(E, E)-3$ isomer] in an isolated yield of $40 \%$ from 2 , with the starting material being recovered in an isolated yield of $37 \%$ (i.e., the overall conversion of starting material to product was about $63 \%)$. It is interesting to note that we did not observe isomerization of $(E, E)-\mathbf{3}$ to $(Z, E)-\mathbf{3}$ during the Baeyer-Villiger oxidation of $\mathbf{2}$. After optimizing the demethylation of $\mathbf{3}$ using boron tribromide, we obtained $\mathbf{1}$ in an isolated yield of $43 \%$, thus completing our two-step synthesis of nepetoidin B in an overall yield of $17 \%$ (33\% when the recovery of starting compound $\mathbf{2}$ is taken into account).

Synthetic nepetoidin B was obtained as a mixture of the two isomers in a ratio of 94:6 $(E, E)-\mathbf{1} /(Z, E)-\mathbf{1}$ (as estimated by ${ }^{1} \mathrm{H}$ NMR analysis; Figures $S 1$ and S2 in the Supporting Information). Considering that the $(E, E)-\mathbf{1}$ isomer was the predominant product in our synthesis, it appears to be the thermodynamically favored isomer. The mixture of the isomers of nepetoidin B [(E,E)-1 94\% and $(Z, E)-\mathbf{1} 6 \%]$ was separated by HPLC. ${ }^{34}$

In conclusion, we have described the first synthesis of nepetoidin B. Currently, commercial sources charge about $\$ 5,000 / \mathrm{g}$ for the product, and so we expect that this convenient synthesis could allow for nepetoidin B to be manufactured at a significantly reduced cost of about $\$ 500 / \mathrm{g}$. Its potential value as a medicinal compound would seem to make this a worthwhile venture.

\section{Funding Information}

The project was funded by Stanford University's Global Climate and Energy Program (GCEP), with analytical facilities (primarily NMR) funded in part by the DOE Great Lakes Bioenergy Research Center (DOE Office of Science BER DE-FC02-07ER64494).

\section{Acknowledgment}

The authors are grateful to Justin Mobley for discussion regarding the Baeyer-Villiger oxidation conditions and Steven D. Karlen for help in separating the isomers of nepetoidin $B$.

\section{Supporting Information}

Supporting information for this article is available online at https://doi.org/10.1055/s-0036-1591556.

\section{References and Notes}

(1) Arihara, S.; Ruedi, P.; Eugster, C. H. Helv. Chim. Acta 1975, 58, 447.

(2) Zhang, P.; Gao, Z. P.; Gao, Y. J.; Xiao, L.; Chen, R. Y.; Kang, J. Zhong Yao Cai 2016, 39, 78.

(3) Zhong, J. D.; Feng, F.; Li, H. Z.; Li, R. T. Journal of Kunming University of Science and Technology (Natural Science Edition) 2013, 38, 75.

(4) Fraga, B. M.; Gonzalez-Coloma, A.; Alegre-Gomez, S.; LopezRodriguez, M.; Amador, L. J.; Diaz, C. E. Phytochemistry 2017, 133, 59.

(5) Nakanishi, T.; Nishi, M.; Inada, A.; Obata, H.; Tanabe, N.; Abe, S.; Wakashiro, M. Chem. Pharm. Bull. 1990, 38, 1772.

(6) Zhong, J. D.; Feng, Y.; Li, H. M.; Xia, X. S.; Li, R. T. Nat. Prod. Res. 2016, 30, 2278.

(7) Huang, Z. Y.; Huang, B.; Xiao, C. J.; Dong, X.; Jiang, B. Nat. Prod. Res. 2015, 29, 628.

(8) Zhou, W.; Xie, H.; Xu, X.; Liang, Y.; Wei, X. J. Funct. Foods 2014, 6, 492.

(9) Tsai, S. F.; Lee, S. S. Phytochemistry 2014, 101, 121.

(10) Banthorpe, D. V.; Bilyard, H. J.; Watson, D. G. Phytochemistry 1985, 24, 2677.

(11) Kubínová, R.; Svajdlenka, E.; Schneiderová, K.; Hanáková, Z.; Dall'Acqua, S.; Farsa, O. Biochem. Syst. Ecol. 2013, 49, 39.

(12) Grayer, R. J.; Eckert, M. R.; Veitch, N. C.; Kite, G. C.; Marin, P. D.; Kokubun, T.; Simmonds, M. S. J.; Paton, A. J. Phytochemistry 2003, 64, 519 .

(13) Wang, G. C.; Li, T.; Deng, F. Y.; Li, Y. L.; Ye, W. C. Bioorg. Med. Chem. Lett. 2013, 23, 1379.

(14) Li, M.; Xu, L.; Li, Z.; Qian, S.; Qin, M. Biochem. Syst. Ecol. 2013, 49, 144.

(15) Banthorpe, D. V.; Bilyard, H. J.; Brown, G. D. Phytochemistry 1989, 28,2109

(16) Falcao, R. A.; do Nascimento, P. L. A.; de Souza, S. A.; da Silva, T. M. G.; de Queiroz, A. C.; da Matta, C. B. B.; Moreira, M. S. A.; Camara, C. A.; Silva, T. M. S. Evid. Based Complementary Altern. Med. 2013, ID 460613.

(17) Murata, T.; Miyase, T.; Yoshizaki, F. J. Nat. Med. 2011, 65, 385.

(18) Shirota, O.; Nagamatsu, K.; Sekita, S. J. Nat. Prod. 2006, 69, 1782.

(19) Brown, G. D.; Banthorpe, D. V. Characteristic Secondary Metabolism in Tissue Cultures of the Labiatae: Two New Chemotaxonomic Markers, In Advances in Labiate Science; Harley, R. M.; 
Reynolds, T.; Atkins, S., Eds.; Royal Botanic Gardens: Kew, 1992, 367.

(20) Wakashiro, M.; Abe, S.; Tanabe, N.; Obata, H. Eur. Pat 0429038 A2, 1990.

(21) Dai, J.; Sorribas, A.; Yoshida, W. Y.; Williams, P. G. Phytochemistry 2010, 71, 2168.

(22) Prisinzano, T. E.; Rothman, R. B. Chem. Rev. 2008, 108, 1732.

(23) Sevindik, H. G.; Ozgen, U.; Atila, A.; Er, H. O.; Kazaz, C.; Duman, H. Chem. Pharm. Bull. 2015, 63, 720.

(24) Hanson, J. R. Sci. Progr. 2010, 93, 171.

(25) Sumaryono, W.; Proksch, P.; Hartmann, T.; Nimtz, M.; Wray, V. Phytochemistry 1991, 30, 3267.

(26) Formisano, C.; Rigano, D.; Senatore, F. Chem. Biodivers. 2011, 8, 1783.

(27) Wu, X.; Gao, H.; Sun, W.; Yu, J.; Hu, H.; Xu, Q.; Chen, X. Phytother. Res. 2017, 31, 1072.

(28) Odonbayar, B.; Murata, T.; Matsumoto, N.; Batkhuu, J.; Sasaki, K. Mongolian Journal of Chemistry 2016, 17, 14.

(29) Venuprasad, M. P.; Kandikattu, H. K.; Razack, S.; Amruta, N.; Khanum, F. Biomed. Pharmacother. 2017, 91, 1.

(30) Beladjila, K. A.; Cotugno, R.; Berrehal, D.; Kabouche, Z.; De Tommasi, N.; Braca, A.; De Leo, M. Nat. Prod. Res. 2017, 20, 1.

(31) Süntar, I.; Nabavi, S. M.; Barreca, D.; Fischer, N.; Efferth, T. Phytother. Res. 2018, 32, 185.

(32) Rinaldi, R.; Jastrzebshi, R.; Clough, M. T.; Ralph, J.; Kennema, M.; Bruijnincx, P. C. A.; Weckhuysen, B. M. Angew. Chem. Int. Ed. 2016, 55, 8164.

(33) Poladura, B.; Martinez-Castaneda, A.; Rodriguez-Solla, H.; Llavona, R.; Concellon, C.; del Amo, V. Org. Lett. 2013, 15, 2810.

(34) Synthesis of 2-(3,4-Dihydroxyphenyl)ethenyl-3-(3,4-dihydroxyphenyl)-2-propenoate (1)

To a stirred solution of (E,E)-3 (1.341 g, $3.620 \mathrm{mmol}, 1.0$ equiv) in dry $\mathrm{CH}_{2} \mathrm{Cl}_{2}(20 \mathrm{~mL})$ under argon was added neat $\mathrm{BBr}_{3}(2.09$ $\mathrm{mL}, 21.722 \mathrm{mmol}, 6.0$ equiv) dropwise at $-78{ }^{\circ} \mathrm{C}$. The solution was stirred at the same temperature for another $30 \mathrm{~min}$, at which point the mixture was allowed to warm to $0{ }^{\circ} \mathrm{C}$ over the course of $1 \mathrm{~h}$, and then to warm to r.t. over the course of $1 \mathrm{~h}$. After once again cooling the mixture to $-78^{\circ} \mathrm{C}$, it was quenched by addition of saturated aqueous $\mathrm{NaHCO}_{3}(18 \mathrm{~mL})$ and then allowed to warm to r.t. over $20 \mathrm{~min}$. The mixture was partitioned between EtOAc $(120 \mathrm{~mL})$ and $\mathrm{H}_{2} \mathrm{O}(150 \mathrm{~mL})$, and the aqueous layer was extracted with EtOAc $(2 \times 50 \mathrm{~mL})$. The combined organic layers were washed with brine $(50 \mathrm{~mL})$, then dried over anhydrous $\mathrm{Na}_{2} \mathrm{SO}_{4}$, and the solution was concentrated in vacuo. The residue was purified by flash column chromatography on silica gel ( $\left.\mathrm{MeOH} / \mathrm{CH}_{2} \mathrm{Cl}_{2} 10: 90\right)$ to furnish nepetoidin $\mathrm{B}$, compound $\mathbf{1}$, as a yellow solid (490 $\mathrm{mg}, 43 \%) . R_{f}=0.58$ $\left(\mathrm{MeOH} / \mathrm{CH}_{2} \mathrm{Cl}_{2}\right.$ 15:85). The ratio of isomers $(E, E)-\mathbf{1} /(Z, E)-\mathbf{1}$ is 94:6, as determined by ${ }^{1} \mathrm{H}$ NMR spectroscopic analysis (signals at $5.67(\mathrm{~d}, J=7.4 \mathrm{~Hz}, \mathrm{H}-7)$ and $6.36(\mathrm{~d}, J=15.8 \mathrm{~Hz}, \mathrm{H}-8)$ for the $(Z, E)-\mathbf{1}$ and $(E, E)-\mathbf{1}$ isomers, respectively).

HPLC Separation of the Isomers of Nepetoidin $B[(E, E)-1$ and $(Z, E)-1]$

The mixture of the isomers of nepetoidin B [(E,E)-1 94\% and $(Z, E)-\mathbf{1} 6 \%]$ obtained from the demethylation of $(E, E)$-3 was separated by HPLC. To collect a sufficient quantity for ${ }^{1} \mathrm{H}$ and ${ }^{13} \mathrm{C}$ NMR analysis, $1(12 \mathrm{mg})$ was dissolved in $\mathrm{MeOH}(350 \mu \mathrm{L})$, and the method described above was run five times using $50 \mu \mathrm{L}$ injections of the solution. The appropriate fractions were combined and concentrated in vacuo to afford each purified isomer for further analysis. $(E, E)-\mathbf{1}(7 \mathrm{mg}):{ }^{1} \mathrm{H}$ NMR $(500 \mathrm{MHz}$, acetone$\left.d_{6}\right): \delta_{\mathrm{H}}=6.36(\mathrm{~d}, J=15.8 \mathrm{~Hz}, \mathrm{H}-8), 6.38\left(\mathrm{~d}, J=12.8 \mathrm{~Hz}, \mathrm{H}-7^{\prime}\right)$, 6.77-6.78 ( $\mathrm{m}, \mathrm{H}-6$ ' and $\mathrm{H}-5), 6.89(\mathrm{~d}, J=8.2 \mathrm{~Hz}, \mathrm{H}-5$ '), 6.93 (d, $J=$ $1.8 \mathrm{~Hz}, \mathrm{H}-2), 7.11$ (dd, $J=8.2,2.1 \mathrm{~Hz}, \mathrm{H}-6), 7.22(\mathrm{~d}, J=2.1 \mathrm{~Hz}$, H-2'), 7.68 (d, $J=15.9 \mathrm{~Hz}, \mathrm{H}-7$ ), 7.81 (d, $\left.J=12.8 \mathrm{~Hz}, \mathrm{H}-8^{\prime}\right), 8.21$ (br. s, $4 \times \mathrm{OH}$ ). The obtained NMR spectroscopic data for $(E, E)-1$ matched literature values. ${ }^{10,15,19}(Z, E)-\mathbf{1}(0.3 \mathrm{mg}):{ }^{1} \mathrm{H}$ NMR (500 MHz, acetone- $\left.d_{6}\right): \delta_{\mathrm{H}}=5.67\left(\mathrm{~d}, J=7.4 \mathrm{~Hz}, \mathrm{H}-7^{\prime}\right), 6.51(\mathrm{~d}, J=15.9$ Hz, H-8), 6.81 (d, J = 8.2 Hz, H-5'), 6.90 (d, J = 8.2 Hz, H-5), 7.00 (dd, $J=8.2,2.1 \mathrm{~Hz}, \mathrm{H}-6$ '), 7.13 (dd, $J=8.2,2.1 \mathrm{~Hz}, \mathrm{H}-6), 7.26$ (d, $J=2.0 \mathrm{~Hz}, \mathrm{H}-2), 7.26$ (d, $\left.J=7.3 \mathrm{~Hz}, \mathrm{H}-8^{\prime}\right), 7.37$ (d, $J=2.1 \mathrm{~Hz}, \mathrm{H}-2$ '), 7.73 (d, $J=15.9 \mathrm{~Hz}, \mathrm{H}-7), 8.05$ (br. s, 4 x OH). ${ }^{1,10,15,19,30}$ 